\title{
Immune condition of the carpet shell clam (Ruditapes decussatus) haemocytes in response to temperature challenge
}

Chalbia Mansour ${ }^{*}$, Fadia Ben Taheur ${ }^{1}$, Sondes Mechri ${ }^{2}$, Bassem Jaouadi ${ }^{2}$, Ridha Mzoughi $^{1}$, Dalila Saidane Mosbahi ${ }^{1}$

*E-mail addresses: chalbia27@yahoo.fr

${ }^{1}$ University of Monastir, Laboratory of Analysis, Treatment and Valorization of Pollutants of the Environment and Products, Faculty of Pharmacy, Ibn Sina Street, 5000 Monastir, Tunisia.

${ }^{2}$ University of Sfax Laboratory of Microbial Biotechnology, Enzymatic, and Biomolecules (LMBEB), Centre of Biotechnology of Sfax (CBS), Road of Sidi Mansour Km 6, P.O. Box 1177, Sfax 3018, Tunisia

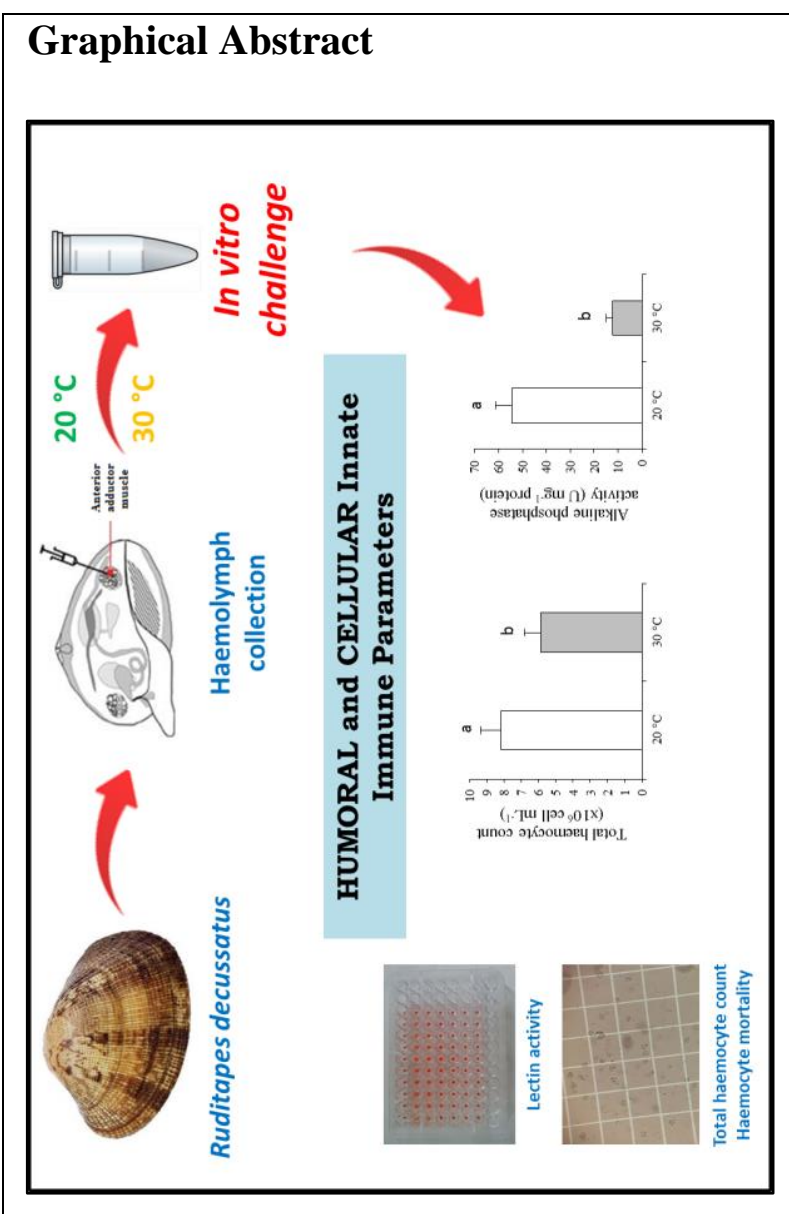

Abstract

The aim of this study was to investigate the immunotoxic effects of acute temperature challenge in the carpet shell clam, Ruditapes decussatus. Haemolymph samples were incubated at 20 and $30{ }^{\circ} \mathrm{C}$ for $24 \mathrm{~h}$. Total haemocyte count (THC), percentage of dead cells (PDC), phenoloxidase (PO), lysozyme (LYZ), alkaline phosphatase (ALP), esterase (EST), lectin (LCT), and antibacterial (AB) activities were chosen as biomarkers of temperature stress. Our results revealed that exposure to high temperatures increases the $\mathrm{AB}$, and the LCT activities while it decreases the THC, the PDC, and the ALP activity. Meanwhile, no obvious negative effect of acute temperature stress was detected on PO, LYZ and EST activities.

Keywords: Ruditapes decussatus; Temperature challenge; Biomarkers; Immune response. 


\section{Introduction}

There is a scientific consensus that human activities are the main driver of climate change, with many impacts on increasing water temperature and acidification. In the last 100 years, the average sea surface temperatures have increased by $0.7{ }^{\circ} \mathrm{C}$. Global temperature should continue to increase of about 1.8 to $4.0{ }^{\circ} \mathrm{C}$ by the end of the 21 st century (IPCC). Water temperature is the most important abiotic environmental factor causing physiological changes in aquatic organisms. Therefore, climate change is a major threat to the economic and ecological sustainability of marine fisheries and aquaculture.

Bivalves are commonly used as sentinel species for monitoring coastal environments (Romeo et al. 2003). Their worldwide distribution, their sessile nature, their filter-feeding and their ability to bioaccumulate pollutants make them ideal species for use in investigation. Host defense mechanisms in bivalve molluscs relies on haemocytes, the circulating cells present in extrapallial fluids, and soluble effectors in haemolymph. Bivalve haemocytes can perform several functions, including wound repair, nodule formation, encapsulation, phagocytosis and cytotoxicity (Cheng 1981). The secretion of soluble factors by haemocytes plays an important role in the immunity of bivalves, indirectly through the regulation of certain cellular mechanisms and directly through their antimicrobial activities. This humoral response involves various molecules such as phenoloxidase cascade, lysosomal enzymes and antimicrobial peptides.

Many studies have reported alterations in immune parameters in various bivalves (oysters, clams, mussels, etc.) when exposed to sudden changes in temperature. In previous studies, a decrease in the haemocyte viability was reported in the thick shell mussel Mytilus coruscus (Wu et al. 2016) and in the green-lipped mussel Perna virdis (Wang et al. 2011) under heat stress. Furthermore, a decrease in phagocytosis was reported in the hard clam Mercenaria mercenaria (Perrigault et al. 2011), in the green-lipped mussel Perna viridis (Wang et al. 2011) and in the thick shell mussel M. coruscus (Wu et al. 2016) after exposure to high temperature. Additionally, Yao et al. (Yao and Somero 2012) reported a decrease in lysosomal membrane stability in mussels $M$. galloprovincialis and $M$. californianus at high and low acclimation temperatures.

In the present research, we assessed the effects of thermal stress on the immune parameters in the carpet shell clam, Ruditapes decussatus. Haemolymph samples were incubated at 20 and $30{ }^{\circ} \mathrm{C}$ for 24 h. Total haemocyte count (THC), percentage of dead cells (PDC), phenoloxidase (PO), lysozyme (LYZ), alkaline phosphatase (ALP), esterase (EST), lectin (LCT), and antibacterial (AB) activities were chosen as biomarkers of heat stress.

\section{Material and methods}

\subsection{Animals}

The carpet shell clams, ( $R$. decussatus) $3-3.5 \mathrm{~cm}$ shell length were purchased from the Bizerta shellfish farming (Bizerta, Tunisia) where they are veterinary and microbiologically controlled. 


\subsection{Experimental protocol}

Animals were maintained in aerated aquaria at $20{ }^{\circ} \mathrm{C}$ and were fed daily, $3 \mathrm{~h}$ before changing the water, with the alga Nannochloripsis ( $3 \times 10^{8}$ cells per day per clam). The alga was provided from the Tunisian Aquaculture Centre (Hergla, Tunisia). Clams were allowed to acclimatise for seven days before being used in the experiments. About $1 \mathrm{~mL}$ of haemolymph was collected per clam from the anterior adductor muscle with a $2 \mathrm{~mL}$ plastic syringe and stored on ice. Samples were incubated at 20 and $30{ }^{\circ} \mathrm{C}$ for $24 \mathrm{~h}$. All the experiments were carried out twice. At the end of the experiments, a volume of $25 \mu \mathrm{L}$ of haemolymph was mixed immediately with formol then was kept at $4{ }^{\circ} \mathrm{C}$ in order to determine the total haemocyte count (THC). To measure enzymatic activities, $500 \mu \mathrm{L}$ of haemolymph were centrifuged $\left(780 \mathrm{x} \mathrm{g}, 10 \mathrm{~min}, 4^{\circ} \mathrm{C}\right)$ and the supernatant, corresponding to cell-free haemolymph, was collected and stored at $-20^{\circ} \mathrm{C}$ until analysis.

\subsection{Cellular innate immunity}

The cellular innate immunity was assessed by calculating the number of free haemocytes and the percentage of dead cells in the hemolymph using a Malassez cell counter. Briefly, a volume of $25 \mathrm{~mL}$ of haemolymph was mixed with the same volume of formol $6 \%$ in order to prevent cell clotting, and the formol was stained with Trypan blue to detect dead cells. Then, the total haemocyte count (THC) and dead haemocyte count (DHC) were expressed as the number of haemocytes $\left(\times 10^{6}\right) \mathrm{mL}^{-1}$ in the haemolymph. The percentage of dead cells (PDC) was expressed as follows:

$\mathrm{PDC}=(\mathrm{DHC} / \mathrm{THC}) * 100$

\subsection{Humoral innate immunity}

\subsubsection{Phenoloxidase activity}

Phenoloxidase (PO) activity assay was performed according to the method described by Asokan et al. (Asokan et al. 1997). Briefly, $50 \mu \mathrm{L}$ of haemolymph were incubated with the same volume of SDS (sodium dodecyl sulphate, $1 \mathrm{mg} \mathrm{mL}^{-1}$, Sigma) for $5 \mathrm{~min}$ at room temperature. To each well were added $50 \mu \mathrm{L}$ of L-DOPA (3,4-dihydroxyphénylalanine, Sigma) $\left(3 \mathrm{mg} \mathrm{mL}^{-1}\right.$ in $0.5 \mathrm{M} \mathrm{HCl}$ containing $10 \mathrm{mM}$ $\mathrm{CaCl}_{2}$ ) as substrate. The decrease of optical density at $490 \mathrm{~nm}$ was followed every minute for $15 \mathrm{~min}$ in a plate reader. PO activity was expressed as units, where one unit represents the change in absorbance $\min ^{-1} \mathrm{mg}$ protein ${ }^{-1}$.

\subsubsection{Lysozyme activity}

Lysozyme activity was measured according to the turbidimetric method described by Parry et al. (Parry et al. 1965)with some modifications. One hundred microlitres of haemolymph were placed in 96-well flat-bottomed plates in triplicate. To each well, $100 \mu \mathrm{L}$ of freeze-dried Micrococcus lysodeikticus $\left(0.3 \mathrm{mg} \mathrm{mL}^{-1}\right.$, Sigma) was added as lysozyme substrate and the reduction in absorbance at $450 \mathrm{~nm}$ was measured after 0 and $15 \mathrm{~min}$ at $22{ }^{\circ} \mathrm{C}$ in a plate reader. One unit of lysozyme activity was defined as a reduction in absorbance of $0.001 \mathrm{~min}^{-1}$. The units of lysozyme present in 
haemolymph were obtained from a standard curve made with hen egg white lysozyme (HEWL, Sigma) and the enzymatic activity was expressed as $\mathrm{U} \mathrm{mg}^{-1}$ proteins.

\subsubsection{Alkaline phosphatase activity}

Alkaline phosphatase activity was quantified as described by Mansour et al. (Mansour et al. 2017). Aliquots of $100 \mu \mathrm{L}$ of haemolymph were mixed with $100 \mu \mathrm{L}$ of $4 \mathrm{mM}$ p-nitrophenyl liquid phosphate (Sigma) in $100 \mathrm{mM}$ ammonium bicarbonate buffer containing $1 \mathrm{mM} \mathrm{MgCl}_{2}$ (pH 7.8, $30{ }^{\circ} \mathrm{C}$ ). ALP activity was determined by recording the increase of OD at $405 \mathrm{~nm}$ every minute for $1 \mathrm{~h}$. ALP activity was expressed as unit $\mathrm{mg}^{-1}$ haemolymph proteins, where one unit represents the amount of enzyme required to release $1 \mu \mathrm{mol}$ of p-nitrophenol phosphate product in $1 \mathrm{~min}$.

\subsubsection{Esterase activity}

Esterase activity was measured by mixing an equal volume of haemolymph samples with $0.4 \mathrm{mM}$ p-nitrophenylmyristate in $100 \mathrm{mM}$ ammonium bicarbonate buffer containing $0.5 \%$ Triton $\mathrm{X}-100(\mathrm{pH}$ $7.8,30^{\circ} \mathrm{C}$ ) as described by Mansour et al. (Mansour et al. 2017). The OD was continuously measured at 1 min intervals over $3 \mathrm{~h}$ at $405 \mathrm{~nm}$ in a plate reader. Standard samples without haemolymph were used as blanks. Esterase activity was expressed as unit $\mathrm{mg}^{-1}$ haemolymph proteins, where one unit represents the amount of enzyme required to release $1 \mu \mathrm{mol}$ of p-nitrophenylmyristate product in 1 $\min$.

\subsubsection{Protein determination}

The total protein concentration present in the haemolymph was measured spectrophotometrically by the Bradford method (Bradford 1976) with a reactive agent (BioRad). Bovine serum albumin was used as standard.

\subsubsection{Antibacterial activity}

Antibacterial activity was measured as described by (Ordás et al. 2000). A $25 \mu$ Lvolume of haemolymph was placed in each well of a 96 well plate. In the control, the haemolymph was substituted by Tryptone soy broth (TSB, Sigma). A volume of $75 \mu \mathrm{L}$ of a suspension of Escherichia coli (ATCC35218) $\left(10^{8}\right.$ cell $\mathrm{mL}^{-1}$ in TSB) was added to each sample, and then the plate was incubated for $3 \mathrm{~h}$ at $18{ }^{\circ} \mathrm{C}$. After that, $100 \mu \mathrm{L}$ of 3-(4,5-Dimethylthiazol-2-yl) 2,5-diphenyltetrazolium bromide (MTT) $\left(0.5 \mathrm{mg} \mathrm{mL}{ }^{-1}\right.$ in TSB) were added to each well. After $15 \mathrm{~min}$ in the dark at $18{ }^{\circ} \mathrm{C}$, the absorbance at $600 \mathrm{~nm}$ was measured. All samples were run in triplicate. The anti-bacterial activity index (BI) was calculated as follows:

$$
\mathrm{BI}=\text { sample } \mathrm{ABS}_{600} / \text { control } \mathrm{ABS}_{600}
$$

\subsubsection{Lectin activity}

Lectin (LCT) activity in haemolymph samples was determined by the reaction of agglutination (HA) following the method described by Ordás et al. (Ordás et al. 2000). This activity was measured 
by adding $25 \mu \mathrm{L}$ of $3 \%$ human blood to $25 \mu \mathrm{L}$ of serially diluted haemolymph in 96-well plates. After mixing, plates were kept at room temperature for $2 \mathrm{~h}$. Agglutination was determined by the presence or the absence of a button of blood on the bottom of the well. The agglutination title (inverse of the highest haemolymph dilution factor) was recorded and expressed as its $\log _{2}$. All samples were run in duplicate.

\subsection{Statistical analysis}

All our results were expressed as mean \pm standard error (SEM). Data were statistically analysed using a one-way analysis of variance (ANOVA). Significant differences were determined at the $p<0.05$ level using Fisher test. Statistical analysis was performed using the software STATISTICA (Statsoft STATISTICA version 6.1.478.0).

\section{Results and Discussion}

\subsection{Cellular innate immunity}

\subsubsection{Total haemocyte count}

Haemocytes are circulating cells involved in bivalve immune defense such as haemocytosis (increases in circulating haemocyte numbers), phagocytosis of small particles, and encapsulation of large particles and production of reactive oxygen species. In the current study, the total haemocyte count (Fig. 1A) was significantly affected by the temperature increase (Fisher test, $p=0.0187$ ). THC was decreased in haemplymph samples kept at $30^{\circ} \mathrm{C}\left(5.89 \pm 0.92 \times 10^{6}\right.$ cell $\left.\mathrm{mL}^{-1}\right)$ compared to clams kept at $20^{\circ} \mathrm{C}\left(8.2 \pm 1.17 \times 10^{6}\right.$ cell $\left.\mathrm{mL}^{-1}\right)$. The effect of temperature on haemocyte density has been widely studied in bivalves. For example, Chen et al. (Chen et al. 2007) appointed to a decrease in THC in the scallop, Chlamys farreri after an increase in temperature from $17{ }^{\circ} \mathrm{C}$ to $28{ }^{\circ} \mathrm{C}$. A similar decrease in THC was recorded in the clam Ruditapes philippinarum kept at $5{ }^{\circ} \mathrm{C}$ and $30{ }^{\circ} \mathrm{C}$ compared with those kept at $15{ }^{\circ} \mathrm{C}$ (Munari et al. 2011). On the contrary, an increase in THC was recorded in the surf clams, Mactraveneri formis, after increasing the temperature from $20{ }^{\circ} \mathrm{C}$ to $30{ }^{\circ} \mathrm{C}$ (Yu et al. 2009). Taking into account, our results and those available in the literature, it seems that the effect of temperature increase on THC can vary among bivalve species.

\subsubsection{Cell viability}

The percentage of dead haemocytes in haemolymph is frequently used as an indicator of the physiological state of bivalves. The results for the percentage of dead cells in our study were surprising. Haemocyte viability was significantly increased by the increase in temperature (Fisher test, $\mathrm{p}=0.0025)$. Indeed, percentage of dead cells was decreased in samples kept at $30{ }^{\circ} \mathrm{C}(10.38 \pm 2.64 \%)$ compared to clams kept at $20{ }^{\circ} \mathrm{C}(31.73 \pm 4.18 \%)$ after a $24 \mathrm{~h}$ incubation (Fig .1B). By contrast, a decrease in the haemocyte viability was reported in the thick shell mussel Mytilus coruscus (Wu et al. 2016) and in the green-lipped mussel Perna virdis (Wang et al. 2011) after increasing the temperature. Furthermore, a decrease in the haemocyte viability was reported in Manila clam $R$. philippinarum, by the decrease of temperature from 14 to $8{ }^{\circ} \mathrm{C}$ (Paillard et al. 2004). Paillard et al. (Paillard et al. 2004) explained this decrease of haemocyte viability at the low temperature by low autophagocytic activity, which is the principle way to eliminate dead haemocytes from circulation (Scro and Ford 1990). Many 
studies have demonstrated the strong effect of temperature on phagocytosis in bivalves. Decreased phagocytosis after exposure to high temperature was reported in the clam Chamelea gallina (Monari et al. 2007), in the hard clam Mercenaria mercenaria (Perrigault et al. 2011), in the green-lipped mussel Perna viridis (Wang et al. 2011) and in the thick shell mussel M. coruscus (Wu et al. 2016). Similar decreases in phagocytosis activity was also observed in the green mussel $P$. viridis after haemocytes exposure to acute temperature challenges (Donaghy and Volety 2011). According to the hypothesis of Paillard et al. (Paillard et al. 2004), an increase of phagocytosis may explain the increase of haemocyte viability recorded in our study at the high temperature. Thus, further studies are needed in order to identify the effect of temperature on the phagocytosis and then on haemocytes viability.

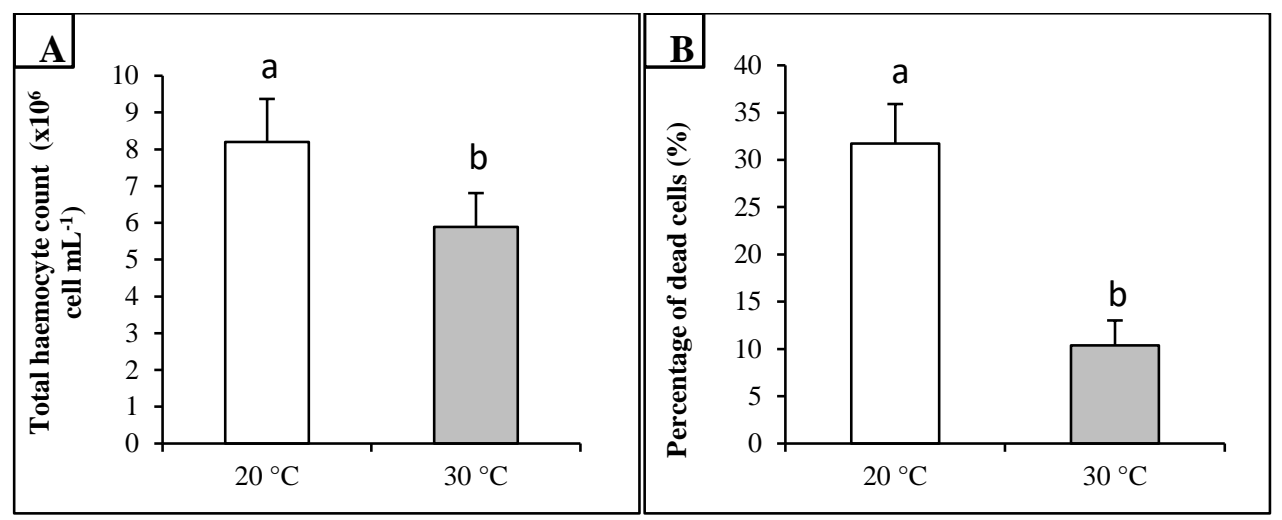

Fig. 1. Total haemocyte count (A) and percentage of dead cells (B) measured in haemolymph of clam, Ruditapes decussatus, after $24 \mathrm{~h}$ incubation at $20^{\circ} \mathrm{C}$ and $30{ }^{\circ} \mathrm{C}$. Data represent the mean \pm SEM. Different letters denote significant differences between treatment groups $(\mathrm{p}<0.05)$.

\subsection{Humoral innate immunity}

\subsubsection{Phenoloxidase activity}

The phenoloxidase system plays a very important role in host defense mechanisms in invertebrates (Munoz et al. 2006), participating in the encapsulation and melanisation of foreign bodies (Söderhäll and Cerenius 1998). Also, it exists in bivalve molluscs such as Mytilus edulis (Coles and Pipe 1994), Mytilus galloprovincialis (Carballal et al. 1997, Carballal et al. 1997), Crassostrea gigas (Gagnaire et al. 2004) and $R$. decussatus (Muñoz et al. 2006). In the present study, the phenoloxidase activity was sligntly influenced by the increase in temperature exposure (Fisher test, p>0.05) (Fig. 2A). There was a tendency for this activity to increase in clams kept at $30{ }^{\circ} \mathrm{C}\left(0.243 \pm 0.054 \mathrm{U} \mathrm{mg}^{-1}\right.$ protein $)$ compared to clams kept at $20{ }^{\circ} \mathrm{C} \quad\left(0.147 \pm 0.040 \mathrm{U} \mathrm{mg}^{-1}\right.$ protein $)$. Few studies have investigated the effect of temperature on the phenoloxidase activity. In freshwater crayfish Pacifastacus leniusculus and Astacus astacus the phenoloxidase activity was not affected by thermal stress (Jiravanichpaisal et al. 2004). Taking into account, our results and those available in the literature, it seems that temperature increase did not influence the phenoloxidase activity in the clam Ruditapes decussatus. 


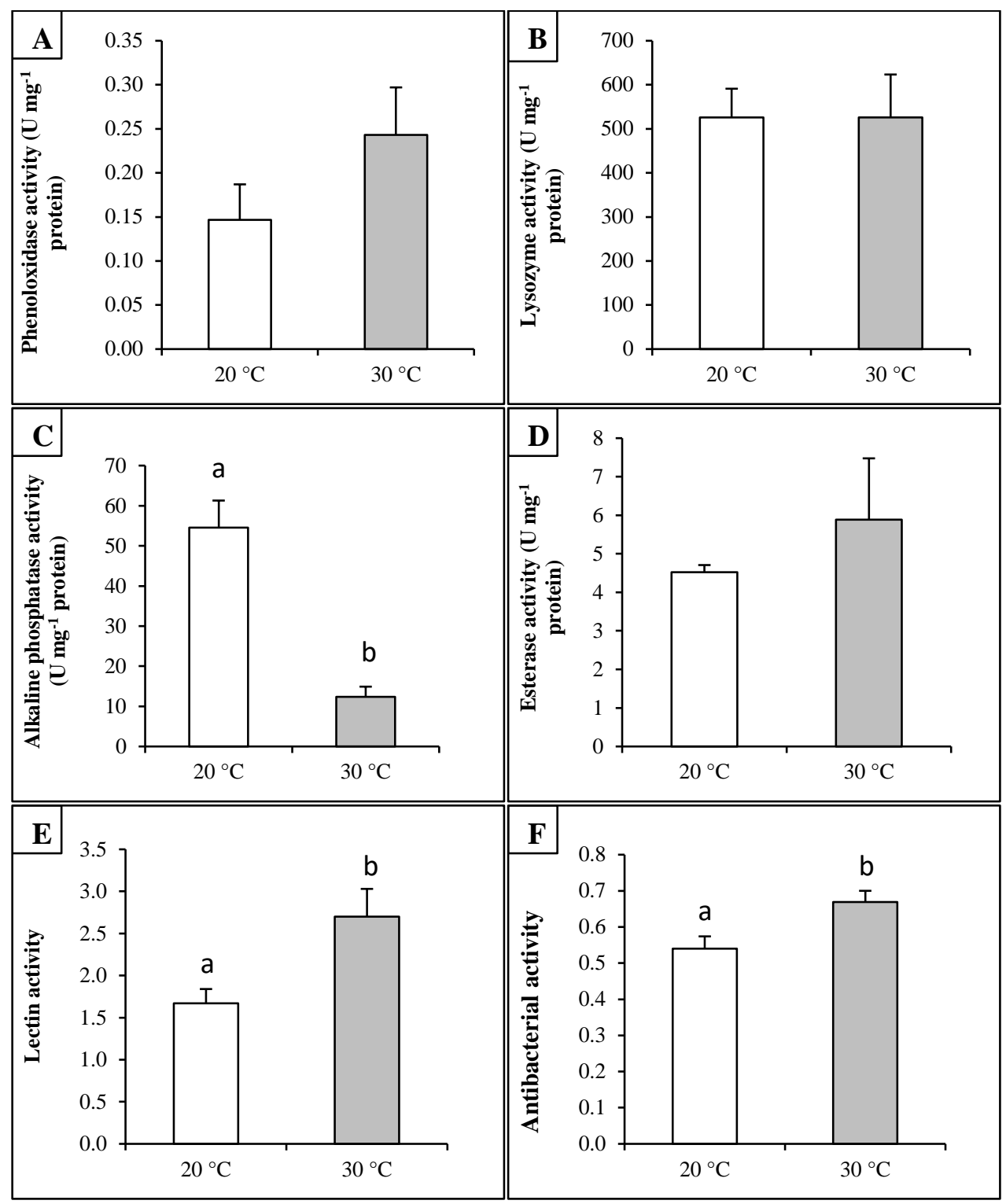

Fig. 2. Phenoloxidase (A), lysozyme (B), alkaline phosphatase (C), esterase (D), lectin (E) and antibacterial (F) activities measured in haemolymph of clam, Ruditapes decussatus, after $24 \mathrm{~h}$ incubation at $20{ }^{\circ} \mathrm{C}$ and $30{ }^{\circ} \mathrm{C}$. Data represent the mean \pm SEM. Different letters denote significant differences between treatment groups $(\mathrm{p}<0.05)$.

\subsubsection{Lysozyme activity}

The release of lysosomal hydrolytic enzymes is an important part of the extracellular killing of bacteria through the hydrolysis of components of bacterial cell walls (Canesi et al. 2002, Monari et al. 2007). Lysozyme is an bacteriolytic agents acting against several species of Gram-positive and Gramnegative bacteria; it is synthesized in bivalve haemocytes and subsequently secreted into haemolymph during phagocytosis (Cheng et al. 1975). In this study, lysozyme activity was measured in cell-free haemolymph to assess possible negative consequences of temperature on enzyme release by haemocytes. In the current study, lysozyme activity was not affected by the increase in temperature (Fisher test, p>0.05) (Fig. 2B). Data concerning effects of temperature on lysozyme activity in bivalves are contradictory. For example, Munari et al. (Munari et al. 2011) reported that temperature did not influence the lysozyme activity in the clam Ruditapes philippinarum. However, exposure to high 
temperature induced an increase of lysozyme secretion from haemocytes into haemolymph in $M$. galloprovincialis (Matozzo et al. 2012) and an increase of lysozyme activity in the Yesso scallop, Patinopecten yessoensis (Jiang et al. 2016). In the opposite, Wu et al. (Wu et al. 2016) reported a decrease of the lysosomal content at high temperature in the thick shell mussel Mytilus coruscus, which was explained by reduction in host defense mechanisms under thermal stress. Similar results were found in the green-lipped mussel Perna viridis (Wang et al. 2011). Both results of the present study and those available in the literature suggest that lysozyme activity can vary among bivalve species. Our observations indicated that high temperature did not influence the lysozyme activity in the clam Ruditapes decussatus.

\subsubsection{Alkaline phosphatase activity}

The alkaline phosphatase (ALP) is a lysosomal enzyme acting on the cell membrane to control trans-membrane transit dynamics (Sarkar 1992) and in the process of mineralisation of the molluscan shell (Gaume et al. 2011). In our in vitro experiments, alkaline phosphatase activity was significantly affected by the temperature, where it was decreased in haemolymph maintained at $30{ }^{\circ} \mathrm{C}$. In our in vitro experiments, haemocyte alkaline phosphatase activity was significantly affected by the temperature (Fisher, p <0.001) after a $24 \mathrm{~h}$ incubation (Fig. 2C). Indeed, this activity was lower in the haemolymph samples incubated at $30^{\circ} \mathrm{C}\left(12.368 \pm 2.536 \mathrm{U} \mathrm{mg}^{-1}\right.$ protein $)$ compared to those incubated at $20^{\circ} \mathrm{C}\left(54.537 \pm 6.748 \mathrm{U} \mathrm{mg}^{-1}\right.$ protein). Contrarily to what observed in the present study, AKP activity was increased in the thick shelled mussel Mytilus coruscus when the temperature increased from 25 to $30{ }^{\circ} \mathrm{C}$ (Hu et al. 2015). Our observations indicated that thermal stress influenced the alkaline phosphatase activity in the clam Ruditapes decussatus. This variation in ALP activity in haemolymph may be explained by a decrease in secretion in order to reduce energy expenditure (Matozzo et al. 2012) and the decrease in the total haemocyte count.

\subsubsection{Esterase activity}

Esterase plays an important role in the immunological defense in mussels, hydrolyzing a number of choline esters, including acetylcholine (Pretti and Cognetti-Varriale 2001). In bivalves, esterase activity was inhibited by neurotoxic compounds (Ozretić and Krajnović-Ozretić 1992, Tsangaris et al. 2008), heavy metals (Najimi et al. 1997) and PAHs (Gagnaire et al. 2006). Therefore, esterase is considered a useful biomarker of pollution. In our experimental conditions, esterase activity was not significantly influenced by the temperature increase (Fisher test, p>0.05) (Fig. 2D), but was slightly higher in haemolymph samples maintained at $30{ }^{\circ} \mathrm{C}\left(5.885 \pm 1.590 \mathrm{U} \mathrm{mg}^{-1}\right.$ protein) compared to those maintained at $20{ }^{\circ} \mathrm{C}\left(4.422 \pm 0.186 \mathrm{U} \mathrm{mg}^{-1}\right.$ protein $)$. In previous study, the esterase activity decreased in the green-lipped mussel $P$. viridis (Wang et al. 2011), in the thick shelled mussel M. coruscus (Wu et al. 2016) and in the Pacific oyster C. gigas (Gagnaire et al. 2006) under high temperatures. Our in vitro experimentations indicated that esterase was insusceptible to high temperature in the carpet shell clam Ruditapes decussatus after haemolymph samples were exposed to such stress.

\subsubsection{Lectin activity}

Lectin activity plays a crucial role in eliminating potential pathogens in marine invertebrates such as bacteria and parasites (Chu 1988). In the present study, the increase in temperature had a significant 
effect on the agglutinating activity (Fig. 2E), which was significantly higher (Fisher test, p=0.045) in the haemolymph samples incubated at $30{ }^{\circ} \mathrm{C}(2.70 \pm 0.33)$ than in those incubated at $20{ }^{\circ} \mathrm{C}(1.67 \pm$ 0.17). No previous study has investigated the effect of temperature on the agglutinating activity. Nevertheless, Ahmad et al. (Ahmad et al. 2011) reported a reduction in plasma agglutination in the bivalve Scrobicularia plana environmentally exposed to mercury. Moreover, Chikalovets et al. (Chikalovets et al. 2010) revealed significant changes in lectin activity in the mussel Mytilus trossulus after exposure to cadmium, detergent and diesel fuel which depend on the contaminant concentration or the time of exposure. This finding has been explained by the adaptive compensatory processes that occur in mollusks subjected to intoxication. Thus, the variations in the level of lectin activity under thermal stress revealed in our study may be explained by a compensatory or adaptative response.

\subsubsection{Antibacterial activity}

In the current study, antibacterial activity (Fig. 2F) was significantly affected by the increase in temperature (Fisher test, $\mathrm{p}=0.014$ ). It was significantly higher in haemolymph incubated at $30{ }^{\circ} \mathrm{C}$ $(0.669 \pm 0.031)$ than in haemolymph incubated at $20{ }^{\circ} \mathrm{C}(0.540 \pm 0.034)$. In these in vitro experimentations, we obtained a significant increase of antibacterial activities under thermal stress. By contrast, exposure to high temperature depressed the antibacterial activity in the abalone, Haliotis rubra (Dang et al. 2012). The increase in the antibacterial activity reported in our experimental conditions may be connected with the increase in the lectin activity.

\subsection{Pearson's correlation coefficients}

Pearson's correlation coefficients between the biomarkers studied are shown in Table 1. A correlation coefficient higher than 0.5 was considered as significant at $\mathrm{P}<0.05$. In our experimental conditions, total haemocyte count was negatively correlated with phenoloxidase activity $(r=-0.719)$ and positively correlated with alkaline phosphatase activity $(\mathrm{r}=0.776)$. Moreover, antibacterial activity was negatively correlated with alkaline phosphatase activity $(\mathrm{r}=-0.828)$ and total haemocyte count $(r=-0.747)$ and lectin activity was positively correlated with esterase activity $(r=0.665)$.

Table 1 Pearson's correlation coefficients (r) of the immune-related parameters studied. Table legend: PO: phenoloxidase; LYZ: lysozyme; ALP: alkaline phosphatase; EST: esterase; LCT: lectin activity; AB: antibacterial activity; THC: total haemocyte count; and PDC: percentage of dead haemocytes.

\begin{tabular}{cllllllll}
\hline & \multicolumn{1}{r}{ PO } & \multicolumn{1}{c}{ LYZ } & ALP & EST & THC & PDC & AB & LCT \\
\hline PO & 1 & & & & & & & \\
LYZ & -0.321 & 1 & & & & & & \\
ALP & -0.290 & 0.016 & 1 & & & & & \\
EST & -0.334 & 0.238 & -0.324 & 1 & & & & \\
THC & $\mathbf{- 0 . 7 1 9}$ & 0.116 & $\mathbf{0 . 7 7 6}$ & -0.133 & 1 & & & \\
PDC & -0.276 & -0.363 & 0.370 & 0.314 & 0.199 & 1 & & \\
AB & 0.385 & 0.053 & $\mathbf{- 0 . 8 2 8}$ & 0.372 & $\mathbf{- 0 . 7 4 7}$ & -0.193 & 1 & \\
LCT & -0.050 & 0.311 & -0.474 & $\mathbf{0 . 6 6 5}$ & -0.447 & 0.027 & 0.475 & 1 \\
\hline
\end{tabular}




\section{Conclusions}

Overall, this study indicates that temperature increase can affect some defense parameters in the carpet shell clam Ruditapes decussatus. Our results show a decrease in total haemocyte count and alkaline phosphatase activity under thermal stress. Moreover, high temperature decreased the percentage of dead haemocytes pointing out an increase of phagocytosis. Furthermore, the present study shows an increase in lectin under thermal stress probably due to a compensatory or adaptative response. Further research is necessary to clarify effects of the acclimation temperature in in vivo experiments in clams and possible protective effects of clams after in vivo challenge to pathogenic bacteria.

\section{Acknowledgements}

This study was supported by the Ministry of Scientific Research and Technology, the University of Monastir (Tunisia).

\section{References}

Ahmad, I., Coelho, J.P., Mohmood, I., Pacheco, M., Santos, M.A., Duarte, A.C. and Pereira, E. (2011) Immunosuppression in the infaunal bivalve Scrobicularia plana environmentally exposed to mercury and association with its accumulation. Chemosphere 82, 1541-1546.

Asokan, R., Arumugam, M. and Mullainadhan, P. (1997) Activation of prophenoloxidase in the plasma and haemocytes of the marine mussel Perna viridis Linnaeus. Dev. Comp. Immunol. 21, 1-12.

Bradford, M. (1976) A rapid and sensitive method for the quantitation of microgram quantities of protein using the principle of protein dye binding. Anal. Biochem. 72, 248-255.

Canesi, L., Gallo, G., Gavioli, M. and Pruzzo, C. (2002) Bacteria-hemocyte interactions and phagocytosis in marine bivalves. Microsc. Res. Tech. 57, 469-476.

Carballal, M., Lopez, M.C., Azevedo, C. and Villalba, A. (1997) Hemolymph cell types of the mussel Mytilus galloprovincialis. Dis. Aquat. Org. 29, 127-135.

Carballal, M.J., Lòpez, C., Azevedo, C. and Villalba, A. (1997) In vitro study of phagocytic ability of Mytilus galloprovincialis Lmk. haemocytes. Fish. Shellfish. Immunol. 7, 403-416.

Chen, M., Yang, H., Delaporte, M. and Zhao, S. (2007) Immune condition of Chlamys farreri in response to acute temperature challenge. Aquaculture 271, 479-487.

Cheng, T. (1981) Bivalves Invertebrate blood cells. Academic Press Inc., New York, 233-300.

Cheng, T.C., Rodrick, G.E., Foley, D.A. and Koehler, S.A. (1975) Release of lysozyme from hemolymph cells of Mercenaria mercenaria during phagocytosis. J. Invertebr. Pathol. 25, 261265.

Chikalovets, I., Chernikov, O., Shekhova, E., Molchanova, V. and Lukyanov, P. (2010) Changes in the level of lectins in the mantle of the mussel Mytilus trossulus in response to anthropogenic contaminants. Russian journal of marine biology 36, 70-74.

Chu, F.-L.E. (1988) Humoral defense factors in marine bivalves. Am Fish Soc Spec Publ 18, 178-188.

Coles, J.A. and Pipe, R.K. (1994) Phenoloxidase activity in the haemolymph and haemocytes of the marine mussel Mytilus edulis. Fish. Shellfish. Immunol. 4, 337-352. 
Dang, V.T., Speck, P. and Benkendorff, K. (2012) Influence of elevated temperatures on the immune response of abalone, Haliotis rubra. Fish. Shellfish. Immunol. 32, 732-740.

Donaghy, L. and Volety, A.K. (2011) Functional and metabolic characterization of hemocytes of the green mussel, Perna viridis: in vitro impacts of temperature. Fish. Shellfish. Immunol. 31, 808814.

Gagnaire, B., Frouin, H., Moreau, K., Thomas-Guyon, H. and Renault, T. (2006) Effects of temperature and salinity on haemocyte activities of the Pacific oyster, Crassostrea gigas (Thunberg). Fish. Shellfish. Immunol. 20, 536-547.

Gagnaire, B., Thomas-Guyon, H., Burgeot, T. and Renault, T. (2006) Pollutant effects on Pacific oyster, Crassostrea gigas (Thunberg), hemocytes: screening of 23 molecules using flow cytometry. Cell. Biol. Toxicol. 22, 1-14.

Gagnaire, B., Thomas-Guyon, H. and Renault, T. (2004) In vitro effects of cadmium and mercury on Pacific oyster, Crassostrea gigas (Thunberg), haemocytes. Fish. Shellfish. Immunol. 16, 501512.

Gaume, B., Fouchereau-Peron, M., Badou, A., Helléouet, M.-N., Huchette, S. and Auzoux-Bordenave, S. (2011) Biomineralization markers during early shell formation in the European abalone Haliotis tuberculata, Linnaeus. Marine Biology 158, 341-353.

Hu, M., Li, L., Sui, Y., Li, J., Wang, Y., Lu, W. and Dupont, S. (2015) Effect of pH and temperature on antioxidant responses of the thick shell mussel Mytilus coruscus. Fish. Shellfish. Immunol. 46, 573-583.

IPCC, C.c.t.p.s.b., in: S. Solomon, D. Qin, M. Manning, Z. Chen, M. Marquis, K.B. Averyt, M. Tignor, H.L. Miller (Eds.), Contribution of Working Group I to the Fourth Assessment Report of the Intergovernmental Panel on Climate Change, Cambridge University Press, Cambridge, 2007, p. 96.

Jiang, W., Li, J., Gao, Y., Mao, Y., Jiang, Z., Du, M., Zhang, Y. and Fang, J. (2016) Effects of temperature change on physiological and biochemical responses of Yesso scallop, Patinopecten yessoensis. Aquaculture 451, 463-472.

Jiravanichpaisal, P., Söderhäll, K. and Söderhäll, I. (2004) Effect of water temperature on the immune response and infectivity pattern of white spot syndrome virus (WSSV) in freshwater crayfish. Fish. Shellfish. Immunol. 17, 265-275.

Mansour, C., Guardiola, F.A., Esteban, M.Á. and Mosbahi, D.S. (2017) Combination of polycyclic aromatic hydrocarbons and temperature exposure: In vitro effects on immune response of European clam (Ruditapes decussatus). Fish. Shellfish. Immunol. 67, 110-118.

Matozzo, V., Chinellato, A., Munari, M., Finos, L., Bressan, M. and Marin, M.G. (2012) First evidence of immunomodulation in bivalves under seawater acidification and increased temperature. PLos One 7.

Monari, M., Matozzo, V., Foschi, J., Cattani, O., Serrazanetti, G.P. and Marin, M.G. (2007) Effects of high temperatures on functional responses of haemocytes in the clam Chamelea gallina. Fish. Shellfish. Immunol. 22, 98-114.

Munari, M., Matozzo, V. and Marin, M.G. (2011) Combined effects of temperature and salinity on functional responses of haemocytes and survival in air of the clam Ruditapes philippinarum. Fish. Shellfish. Immunol. 30, 1024-1030. 
Munoz, P., Meseguer, J. and Esteban, M.Á. (2006) Phenoloxidase activity in three commercial bivalve species. Changes due to natural infestation with Perkinsus atlanticus. Fish. Shellfish. Immunol. 20, 12-19.

Muñoz, P., Meseguer, J. and Esteban, M.Á. (2006) Phenoloxidase activity in three commercial bivalve species. Changes due to natural infestation with Perkinsus atlanticus. Fish. Shellfish. Immunol. 20, 12-19.

Najimi, S., Bouhaimi, A., Daubeze, M., Zekhnini, A., Pellerin, J., Narbonne, J. and Moukrim, A. (1997) Use of acetylcholinesterase in Perna perna and Mytilus galloprovincialis as a biomarker of pollution in Agadir Marine Bay (South of Morocco). Bull. Environ. Contam. Toxicol. 58, 901-908.

Ordás, M.C., Ordás, A., Beloso, C. and Figueras, A. (2000) Immune parameters in carpet shell clams naturally infected with Perkinsus atlanticus. Fish. Shellfish. Immunol. 10, 597-609.

Ozretić, B. and Krajnović-Ozretić, M. (1992) Esterase heterogeneity in mussel Mytilus galloprovincialis: effects of organophosphate and carbamate pesticides in vitro. Comp. Biochem. Physiol. C Pharmacol. Toxicol. Endocrinol. 103, 221-225.

Paillard, C., Allam, B. and Oubella, R. (2004) Effect of temperature on defense parameters in Manila clam Ruditapes philippinarum challenged with Vibrio tapetis. Dis. Aquat. Org. 59, 249-262.

Parry, R.M., Jr., Chandan, R.C. and Shahani, K.M. (1965) A rapide and sensitive assay of muramidase. Proc. Soc. Exp. Biol. Med. 119, 384-386.

Perrigault, M., Dahl, S.F., Espinosa, E.P., Gambino, L. and Allam, B. (2011) Effects of temperature on hard clam (Mercenaria mercenaria) immunity and QPX (Quahog Parasite Unknown) disease development: II. Defense parameters. J. Invertebr. Pathol. 106, 322-332.

Pretti, C. and Cognetti-Varriale, A.M. (2001) The use of biomarkers in aquatic biomonitoring: the example of esterases. Aquat. Conserv. 11, 299-303.

Romeo, M., Hoarau, P., Garello, G., Gnassia-Barelli, M. and Girard, J.P. (2003) Mussel transplantation and biomarkers as useful tools for assessing water quality in the NW Mediterranean. Environ. Pollut. 122, 369-378.

Sarkar, A. (1992) Evaluation of the Toxicity of Organic Matter in Marine Sediments. Water Science and Technology 25, 255-257.

Scro, R.A. and Ford, S.E. (1990). An electron microscope study of disease progression in the oyster, Crassostrea virginica, infected with the protozoan parasite, Haplosporidium nelsoni (MSX). Pathology in Marine Science, Academic Press London \& New York: 229-254.

Söderhäll, K. and Cerenius, L. (1998) Role of the prophenoloxidase-activating system in invertebrate immunity. Current opinion in immunology 10, 23-28.

Tsangaris, C., Papathanassiou, E. and Nicolaidou, A. (2008) Biochemical biomarkers and overall health status of mussels Mytilus galloprovincialis exposed to nickel and chromium. Chemistry and Ecology 24, 315-327.

Wang, Y., Hu, M., Shin, P.K. and Cheung, S.G. (2011) Immune responses to combined effect of hypoxia and high temperature in the green-lipped mussel Perna viridis. Mar. Pollut. Bull. 63, 201-208.

Wu, F., Lu, W., Shang, Y., Kong, H., Li, L., Sui, Y., Hu, M. and Wang, Y. (2016) Combined effects of seawater acidification and high temperature on hemocyte parameters in the thick shell mussel Mytilus coruscus. Fish. Shellfish. Immunol. 56, 554-562. 
Yao, C.L. and Somero, G.N. (2012) The impact of acute temperature stress on hemocytes of invasive and native mussels (Mytilus galloprovincialis and Mytilus californianus): DNA damage, membrane integrity, apoptosis and signaling pathways. J. Exp. Biol. 215, 4267-4277.

Yu, J.H., Song, J.H., Choi, M.C. and Park, S.W. (2009) Effects of water temperature change on immune function in surf clams, Mactra veneriformis (Bivalvia: Mactridae). J. Invertebr. Pathol. $102,30-35$. 